\title{
Impaired Cardiac Muscarinic Receptor Function in Dogs with Heart Failure
}

Dorothy E. Vatner, David L. Lee, Kurt R. Schwarz, J. Peter Longabaugh, Alan M. Fujii, Stephen F. Vatner, and Charles J. Homcy Departments of Medicine, Harvard Medical School, Brigham and Women's Hospital, Cardiac Unit and Childrens' Service, Massachusetts General Hospital, Boston, Massachusetts 02114; and New England Regional Primate Research Center, Southborough, Massachusetts 01772

\begin{abstract}
Prior physiological studies have suggested that parasympathetic control is altered in heart failure. The goal of our studies was to investigate the influence of heart failure on the muscarinic receptor, and its coupling to adenylate cyclase. Ligand binding studies using $\left[{ }^{3} \mathbf{H}\right]$ quinuclidinyl benzilate and enriched left ventricular (LV) sarcolemma, demonstrated that muscarinic receptor density in heart failure declined $36 \%$ from a control of $5.6 \pm 0.6 \mathrm{pmol} / \mathrm{mg}$, with no change in antagonist affinity. However, agonist competition studies with both carbachol and oxotremorine showed that it was a loss of high affinity agonist binding sites in the sarcolemma from failing $L V$ that accounted for this difference.

The functional efficacy of the muscarinic receptor was also examined. When $1 \mu \mathrm{M}$ methacholine was added to $0.1 \mathrm{mM}$ GTP and $0.1 \mathrm{mM}$ isoproterenol, adenylate cyclase stimulated activity was inhibited by $15 \%$ in normal $\mathrm{LV}$ but only $5 \%$ in $\mathrm{LV}$ sarcolemma from animals with heart failure even when the reduced adenylate cyclase in these heart failure animals was taken into account. Even at $\mathbf{1 0 0}$-fold greater concentrations of methacholine, significantly less inhibition of adenylate cyclase activity was observed in LV failure as compared with normal LV sarcolemma. Levels of the GTP-inhibitory protein known to couple the muscarinic receptor to adenylate cyclase, as measured with pertussis toxin labeling, were not depressed in $\mathrm{LV}$ failure. Thus, the inhibitory pathway regulating $\mathrm{LV}$ adenylate cyclase activity is defective in heart failure. The decrease in muscarinic receptor density, and in particular the specific loss of the high affinity agonist binding component of this receptor population, appears to be the major factor underlying this abnormality.
\end{abstract}

\section{Introduction}

Several abnormalities in the autonomic control of cardiac function have been identified in heart failure (1-5). While most work has focused on alterations in adrenergic mechanisms, defective parasympathetic regulation of the failing heart has also been surmised from the findings of depressed chronotropic responses to atropine and reduced baroreflex slowing of heart rate in response to an acute elevation in arterial pressure

Address correspondence to Dr. Vatner, Cellular and Molecular Research, Jackson 13, Massachusetts General Hospital, Boston, MA 02114.

Received for publication 18 June 1987 and in revised form 28 December 1987.

J. Clin. Invest.

(c) The American Society for Clinical Investigation, Inc.

0021-9738/88/06/1836/07 \$2.00

Volume 81 , June 1988, 1836-1842
(2-4). Since the mechanism of reflex bradycardia in response to baroreceptor hypertension is primarily vagal $(6,7)$, this suggests defective parasympathetic control of the failing heart. This defect could be located in the vagus, the central nervous system, at the muscarinic receptor itself; or in its transduction mechanism. Muscarinic receptor activation can affect directly a variety of cellular systems which leads to alterations in cardiac rate and contractility (1). One well-defined mechanism of muscarinic receptor function involves inhibition of adenylate cyclase activity. We have recently observed that in a model of chronic left ventricular (LV) ${ }^{1}$ failure in the dog, muscarinic receptor density is reduced (5). The ligand binding studies from that study were conducted using a relatively crude membrane preparation.

To extend these preliminary observations, the present investigation was designed to determine if $(a)$ a decrease in muscarinic receptor density was present in an enriched sarcolemmal preparation from failing LV (8), (b) abnormalities in agonist binding could also be identified, $(c)$ muscarinic inhibition of adenylate cyclase activity, one type of functional measure of muscarinic receptor activity (9), was also depressed, and (d) levels of inhibitory guanine nucleotide-binding proteins (10-12) were altered.

\section{Methods}

Mongrel puppies of either sex at 7-10 wk were anesthetized with sodium thiamylal $(10 \mathrm{mg} / \mathrm{kg})$, and then halothane ( $1 \mathrm{vol} \%)$, and ventilated with a Harvard respirator. A right thoracotomy was performed through the 4th intercostal space using sterile surgical technique. The ascending aorta above the coronary arteries was isolated and dissected free of surrounding tissue. A $1-\mathrm{cm}$ wide Teflon cuff was placed around the aorta, tightened until a thrill was palpable over the aortic arch, and the chest was closed. Nine dogs with chronic pressure overload developed LV failure spontaneously, 9 mo to $2 \mathrm{yr}$ after banding. Animals used in this study were maintained in accordance with the guidelines of the Committee on Animals of the Harvard Medical School and the Guide for Care and Use of Laboratory Animals (Department of Health and Human Services publication No. [National Institutes of Health] 85-23, revised 1985).

The data from the group of nine dogs with LV failure were compared with a group of 10 normal dogs, one of which was a sham-operated littermate of the dogs with LV failure. LV and arterial pressures were measured in the conscious dogs using a calibrated Millar micromanometer catheter. The catheter was introduced retrogradely into the LV using a femoral artery approach under local anesthesia with lidocaine $2 \%$. Pressures were recorded on a multichannel oscillograph.

After the dogs were anesthetized with sodium pentobarbital, 30 $\mathrm{mg} / \mathrm{kg}$, the hearts were immediately excised and placed into iced saline. All subsequent procedures were carried out at $4^{\circ} \mathrm{C}$. Enriched sarcolemma membranes were prepared according to the method of

1. Abbreviations used in this paper: $\mathrm{LV}$, left ventriculars; $\left[{ }^{3} \mathrm{H}\right] \mathrm{QNB}$, $\left[{ }^{3} \mathrm{H}\right]$ quinaclidinyl benzilate. 
Jones and Besch (8). The sarcolemma were prepared by mincing and homogenizing the tissue in $4 \mathrm{vol}$ of buffer $(0.75 \mathrm{M} \mathrm{NaCl}$ and $10 \mathrm{mM}$ histidine) for $5 \mathrm{~s}$ at low speed with a polytron (Brinkmann Instruments Co., Westbury, NY). The homogenate was centrifuged for $15 \mathrm{~min}$ at $14,000 \mathrm{~g}$ and the resulting pellet was resuspended in the same buffer. This step was repeated twice and the pellet was resuspended in $10 \mathrm{mM}$ $\mathrm{NaHCO}_{3}$ and $5 \mathrm{mM}$ histidine buffer and then the pellet was homogenized for $30 \mathrm{~s}$ three times at one-half speed with a polytron. The homogenate was centrifuged at $14,000 \mathrm{~g}$ for $20 \mathrm{~min}$ and the supernatant was saved and centrifuged at $44,000 \mathrm{~g}$ for $30 \mathrm{~min}$. The pellet was resuspended in distilled water, and an equal volume of $2 \mathrm{M}$ sucrose was added and then layered at the bottom of a sucrose density gradient containing $1.0,0.6$, and $0.25 \mathrm{M}$ sucrose. The yield from this preparation was $7 \pm 1 \mathrm{mg}$ enriched sarcolemma protein per $100 \mathrm{~g}$ of $\mathrm{LV}$ for normal hearts, which was not significantly different from failing hearts $(6 \pm 2 \mathrm{mg} / 100 \mathrm{~g})$. A crude membrane preparation was also prepared as previously described (5). The crude membrane preparation was used solely for the agonist binding experiments. The heart was trimmed, minced, homogenized, and centrifuged at $1,000 \mathrm{~g}$ for $15 \mathrm{~min}$ in buffer ( $0.25 \mathrm{M}$ sucrose, $1 \mathrm{mM} \mathrm{KHCO}, 1 \mathrm{mM}$ EDTA). The supernatant was centrifuged at $45,000 \mathrm{~g}$ for $15 \mathrm{~min}$. The pellet was resuspended in the same buffer and centrifuged two more times. The yield from this preparation was $\sim 100 \mathrm{mg}$ protein per $100 \mathrm{~g} \mathrm{LV}$.

$\mathrm{Na}^{+}, \mathrm{K}^{+}$-ATPase activity was determined according to the method of Jones and Besch (8). $\mathrm{Na}^{+}, \mathrm{K}^{+}$-ATPase activity, a membrane-associated protein that is not involved in ligand binding, was used as a marker for sarcolemma content. The enriched sarcolemma-associated activity of $\mathrm{Na}^{+}, \mathrm{K}^{+}$ATPase was $26.8 \pm 3.4 \mu \mathrm{mol}$ inorganic phosphate $\left(P_{i}\right) / h$ per $\mathrm{mg}$ in the normal $\mathrm{LV}$ and not significantly different $\left(24.0 \pm 3.4 \mu \mathrm{mol} \mathrm{P}_{\mathrm{i}} / \mathrm{h}\right.$ per $\left.\mathrm{mg}\right)$ in the failing $\mathrm{LV}$.

All studies were performed in the presence of $100 \mathrm{mM}$ Tris, $5 \mathrm{mM}$ $\mathrm{MgCl}_{2}$, and $1 \mathrm{mM}$ EGTA, $\mathrm{pH}$ 7.2. Antagonist binding studies were performed using $100 \mu \mathrm{l}\left[{ }^{3} \mathrm{H}\right]$ quinuclidinyl benzilate $\left({ }^{3} \mathrm{H}-\mathrm{QNB}\right), 0.05-3$ $\mathrm{nM}, 100 \mu \mathrm{l}$ atropine $(1 \mu \mathrm{M})$ or buffer, and $800 \mu \mathrm{l}$ of membrane protein (2-4 $\mu \mathrm{g} /$ tube). Agonist competitive inhibition binding studies were performed with ${ }^{3} \mathrm{H}-\mathrm{QNB}$, and with increasing concentrations $(0.001-$ $100 \mu \mathrm{M})$ of carbachol and oxotremorine in the presence and absence of $0.1 \mathrm{mM} \mathrm{Gpp}(\mathrm{NH}) \mathrm{p}$. Assays were performed in duplicate, incubated at $37^{\circ} \mathrm{C}$ for $30 \mathrm{~min}$, terminated by rapid filtration on Whatman glass fiber/C filters, and counted in $10 \mathrm{ml}$ Hydrofluor (National Diagnostics, Manville, NJ) for $5 \mathrm{~min}$. Nonspecific binding as determined by $1 \mu \mathrm{M}$ atropine, comprised $10 \%$ of the total binding. Specific binding was determined by subtracting the nonspecific from the total binding. The binding data were analyzed by the "Ligand" program of Munson and Rodbard (13). In the computer analysis, the F test was used to compare the best fit for the ligand binding competition data. The three-site vs. two-site fit was determined by the $P$ value for the $F$ test, and by the change in the residual sum of squares for the various fits. One-, two-, and three-site models were tested and the model yielding the least residual sum of squares was used to describe the data. The $P$ values and the residual sum of squares for the normal LV indicated that the three-site fit was preferred over the two-site fit, for the inhibition curve using carbachol as the competing ligand.

The adenylate cyclase assays were performed in a total volume of $0.15 \mathrm{ml}$ containing sarcolemma protein (10-20 $\mu \mathrm{g}), 100 \mathrm{mM}$ Tris (pH 7.2), $1 \mathrm{mM}$ EGTA, $15 \mathrm{mM} \mathrm{MgCl} 2,2 \mu \mathrm{Ci}\left[\alpha-{ }^{32} \mathrm{P}\right] \mathrm{ATP}, 0.2 \mathrm{mM}$ ATP, 7 $\mathrm{mM}$ creatine phosphate, $1 \mathrm{U}$ creatine phosphokinase, $0.3 \mathrm{mM}$ cyclic AMP, $\left[{ }^{3} \mathrm{H}\right]$ cyclic AMP $(10,000 \mathrm{cpm}, 40 \mathrm{Ci} / \mathrm{mmol})$, and one or more of the following: $0.1 \mathrm{mM}$ GTP, $0.1 \mathrm{mM}$ or $0.3 \mu \mathrm{M}$ isoproterenol, $1 \mu \mathrm{M}$ atropine, and 0.03-100 $\mu \mathrm{M}$ methacholine. Maximal adenylate cyclase activity was assessed by measuring cyclic AMP production in the presence of $0.1 \mathrm{mM}$ isoproterenol plus $0.1 \mathrm{mM}$ GTP. Adenylate cyclase activity was linear, with time of incubation from 1 to $30 \mathrm{~min}$. Increasing concentrations of the muscarinic agonist methacholine $(0.03 \mu \mathrm{M}$ to $0.1 \mathrm{mM}$ ) were used to inhibit adenylate cyclase activity that was stimulated by isoproterenol $(0.3 \mu \mathrm{M})$ plus GTP $(0.1 \mathrm{mM}) .{ }^{32} \mathrm{P}$-Cyclic AMP was quantitated according to the method of Salomon et al. (14). The inhibition of adenylate cyclase activity by methacholine was com- pletely blocked with atropine $(1 \mu \mathrm{M})$. The protein concentrations for each assay were determined by the method of Lowry et al. (15).

The pertussis toxin-catalyzed ADP ribosylation of the sarcolemmal GTP-binding proteins was carried out according to the method of Bokoch et al. (11). Enriched sarcolemma was solubilized in a $2 \%$ cholate solution for $60 \mathrm{~min}$ immediately before ADP ribosylation. The solubilized membranes $(3 \mathrm{mg} / \mathrm{ml})$ were then diluted $1: 20$ in $20 \mathrm{mM}$ Tris $\mathrm{HCl}, \mathrm{pH} 8.0,1 \mathrm{mM}$ EDTA, $1 \mathrm{mM}$ dithiothreitol, and $0.05 \%$ Lubrol (Sigma Chemical Co., St. Louis, MO). The reaction was begun by adding $10 \mu \mathrm{l}$ of this solution, which contained $1.5 \mu \mathrm{g}$ of solubilized sarcolemma, to $26 \mu \mathrm{l}$ of a reaction buffer containing $3 \mu \mathrm{g} / \mathrm{ml}$ pertussis toxin and $1.0 \mu \mathrm{M}\left[{ }^{32} \mathrm{P}\right] \mathrm{NAD}$, and then the reaction mixture was incubated at $30^{\circ} \mathrm{C}$ for the times indicated. The reaction was stopped by the addition of 3 vol of solubilization buffer. The samples were then run on a $17 \%$ polyacrylamide gel and autoradiography was carried out overnight. Individual bands representing the inhibitory guanine nucleotide regulatory proteins $G_{i}$ and $G_{0}$ were cut out separately, and counted in $10 \mathrm{ml}$ of a toluene-based scintillation mixture. An equivalent area of each lane was cut out for background measurement, and the reported values represented total band counts minus background counts. ADP ribosylation values were reported as picomoles of [ $\left.{ }^{32} \mathrm{P}\right] \mathrm{ADP}$-ribose incorporated per milligram of membrane protein added.

Data were expressed as mean value \pm SEM, and stored in a Digital computer (PDP-11/34). Statistical evaluation was performed by Student's $t$ test between groups (16).

\section{Results}

Quantitation of receptor density in $L V$ failure. In the 9 dogs with LV failure as compared with 10 normal animals, LV weight, LV free wall weight/body weight, LV systolic, and end-diastolic pressures were elevated, $P<0.01$ (Table I). The increased $L V$ end-diastolic pressure $(33 \pm 4.3$ vs. $8.1 \pm 0.7$ $\mathrm{mmHg}$ for controls) indicated that $\mathrm{LV}$ hypertrophy was no longer compensated. LV failure, reflected by pulmonary vascular congestion, was confirmed in all dogs at autopsy.

Using an enriched sarcolemmal membrane preparation (8), muscarinic receptor density, as assessed with the muscarinic antagonist $\left[{ }^{3} \mathrm{H}\right] \mathrm{QNB}$, was reduced significantly, $P<0.05$, in the LV of animals with heart failure $(3.6 \pm 0.4 \mathrm{pmol} / \mathrm{mg}, n$ $=8)$ compared with normal LV sarcolemma $(5.6 \pm 0.6 \mathrm{pmol} /$ $\mathrm{mg}, n=10)$. The affinity for $\left[{ }^{3} \mathrm{H}\right] \mathrm{QNB}$ was similar in normal $(0.12 \pm 0.02 \mathrm{nM})$ as compared with failing $L V(0.13 \pm 0.02 \mathrm{nM})$ (Fig. 1).

Quantitation of agonist high affinity sites in LV failure. Muscarinic agonist binding was examined by performing competition studies with both carbachol (Fig. 2) and oxotrem-

Table I. Morphology and Hemodynamics

\begin{tabular}{lcc}
\hline & $\begin{array}{c}\text { Normal } \\
(n=10)\end{array}$ & $\begin{array}{c}\text { LV failure } \\
(n=9)\end{array}$ \\
\hline Body weight $(\mathrm{kg})$ & $25 \pm 1.3$ & $22 \pm 0.8$ \\
LV. weight $(\mathrm{g})$ & $81 \pm 5.1$ & $157 \pm 9.9^{*}$ \\
$\mathrm{LV}$ weight/body weight $(\mathrm{g} / \mathrm{kg})$ & $3.4 \pm 0.1$ & $7.1 \pm 0.4^{*}$ \\
LV systolic pressure $(\mathrm{mmH} H)$ & $129 \pm 3.0$ & $270 \pm 28^{*}$ \\
LV end-diastolic pressure $(\mathrm{mmHg})$ & $8.1 \pm 0.7$ & $33 \pm 4.3^{*}$ \\
Mean arterial pressure $(\mathrm{mmHg})$ & $94 \pm 4.0$ & $100 \pm 6.7$ \\
Heart rate $($ beats/minute $)$ & $94 \pm 5.0$ & $139 \pm 14^{\ddagger}$
\end{tabular}

* $P<0.01$ from normal values.

${ }^{\ddagger} P<0.05$ from normal values. 


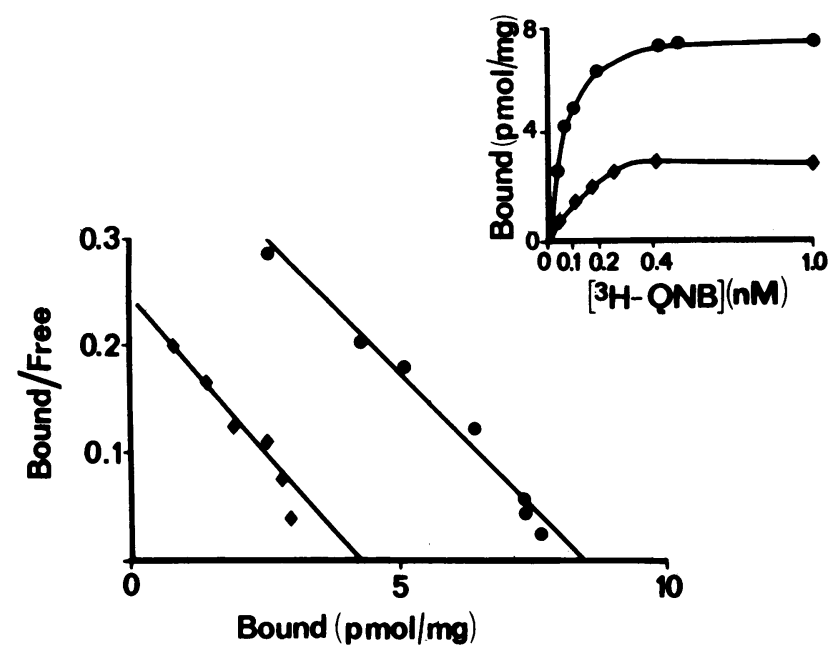

Figure 1. Scatchard analyses of muscarinic receptor binding to LVenriched sarcolemma are compared in the normal heart (circles) and in the heart with LV failure (diamonds). The LV failure heart shows a similar affinity and fewer receptors per milligram protein than the normal LV. The inset shows a saturation plot of the same data.

orine (Fig. 3). This was carried out since previous reports have indicated that the number and percentage of interactive high affinity sites detected with these two agonists may be different $(17,18)$. Using the crude membrane preparation from normal $\mathrm{LV}$, agonist competition binding curves with $\left[{ }^{3} \mathrm{H}\right] \mathrm{QNB}$ and 15 to 22 concentrations $\left(10^{-10}-10^{-4} \mathrm{M}\right)$ of carbachol, were fitted best to a three-site model (Fig. 4). Sarcolemma from failure LV showed a complete loss of the superhigh affinity site and a 50\% reduction in the concentration of the high affinity site (Fig. 4). Using oxotremorine for agonist binding, the data best fit a two-site model for normal LV, i.e., high and low affinity sites, in the membranes from the normal dogs. In LV failure, the number of high affinity sites $(56 \pm 9 \mathrm{fmol} / \mathrm{mg})$ was significantly reduced, $P<0.05$, from that observed in normal dogs $(89 \pm 9$

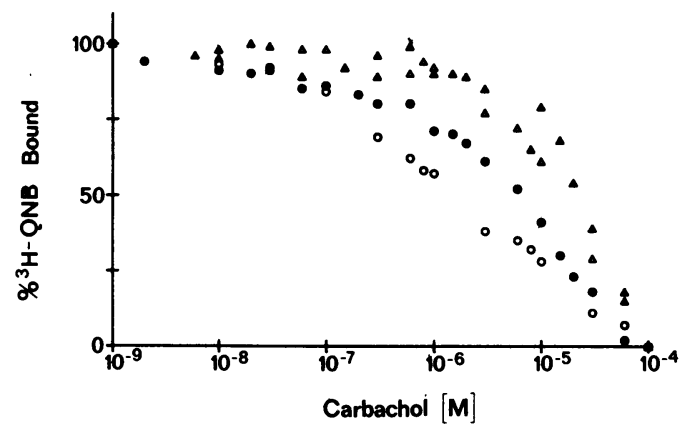

Figure 2. Competitive inhibition binding is shown in sarcolemma membranes from the normal LV of a single animal with increasing concentrations of carbachol. In the normal LV in the absence of $\mathrm{Gpp}(\mathrm{NH}) \mathrm{p}$ (open circles), the binding curve has a shallow slope and fits best to three affinity sites. In the presence of $\mathrm{Gpp}(\mathrm{NH}) \mathrm{p}$ (open triangles), the curve shifts to the right and steepens to fit two affinity sites. In sarcolemma from the failing $\mathrm{LV}$ of a single animal, the absence of $\mathrm{Gpp}(\mathrm{NH}) \mathrm{p}$ ( filled circles) results in a binding curve that is shifted to the right of the normal LV and fits best to two affinity sites. In the presence of $\mathrm{Gpp}(\mathrm{NH}) \mathrm{p}$ ( filled triangles), the curve shifts further to the right and fits best to a single affinity site.

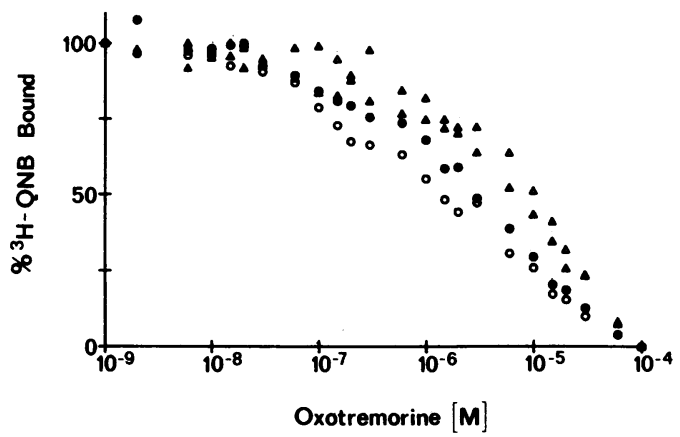

Figure 3. Competitive inhibition binding is shown in sarcolemma membranes from normal LV of a single animal and failing $\mathrm{LV}$ of a single animal, with increasing concentrations of oxotremorine. Binding to sarcolemma from normal LV, in the absence of Gpp(NH)p (open circles), results in a shallow slope and fits best to two affinity sites. In the presence of Gpp(NH)p (open triangles), the curve steepens and shifts to the right. With $\mathrm{LV}$ failure, in the absence of $\mathrm{Gpp}(\mathrm{NH}) \mathrm{p}$ ( filled circles), the binding curve is shifted to the right of the normal LV. In the presence of Gpp(NH)p (filled triangles), the curve shifts only slightly further to the right.

$\mathrm{fmol} / \mathrm{mg}$ ) (Table II). In the presence of $0.1 \mathrm{mM} \mathrm{Gpp}(\mathrm{NH}) \mathrm{p}$, all curves shifted to the right into a low affinity state.

Functional efficacy of muscarinic receptor activation in $L V$ failure. Basal adenylate cyclase activity was lower in LV sarcolemma of animals with failure ( $385 \pm 51 \mathrm{pmol}$ cyclic AMP $/ \mathrm{mg}$ per min, $n=5)$ as compared with normal animáls (804 \pm 121 pmol cyclic AMP/mg per min, $n=6$ ). Maximal $\beta$-adrenergic receptor-mediated stimulation of adenylate cyclase by 0.1 $\mathrm{mM}$ isoproterenol and $0.1 \mathrm{mM} \mathrm{GTP}$ was also significantly less, $P<0.05$, in LV failure $(815 \pm 138 \mathrm{pmol}$ cyclic AMP/mg per min) compared with normal hearts $(2,238 \pm 427$ pmol cyclic AMP/mg per min) as previously reported (5).

When this maximal isoproterenol $(0.1 \mathrm{mM})$ stimulation was inhibited with $1 \mu \mathrm{M}$ methacholine, adenylate cyclase activity was reduced by $15 \pm 2.7 \%$ ( $244 \pm 87$ pmol cyclic AMP $/ \mathrm{mg}$ per min) in normal LV and significantly less, $P<0.01$, by only $5 \pm 2.1 \%(25 \pm 9.4 \mathrm{pmol}$ cyclic AMP/mg per miń) in the failing LV. The reduced inhibition of adenylate cyclase activity in LV failure was observed both with and without subtracting basal cyclase activity (Fig. 5). After the addition of $1 \mu \mathrm{M}$ atropine, the inhibition in $0.1 \mathrm{mM}$ isoproterenol-stimulated adenylate

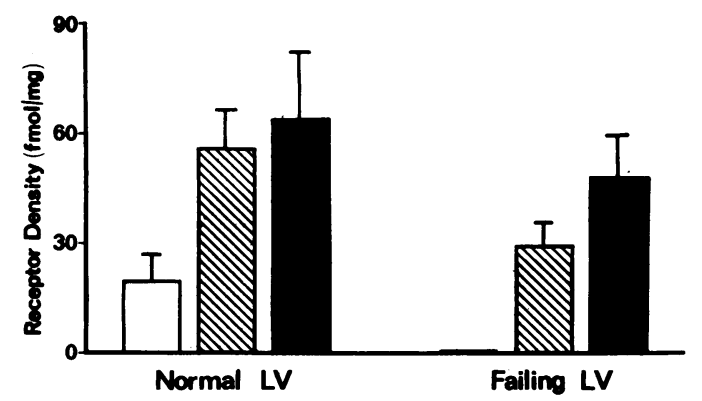

Figure 4. The average \pm standard error of the mean number of superhigh (open bar), high (hatched bars), and low (solid bars) affinity sites as determined by computer modeling of carbachol competitive inhibition curves with normal $(n=7)$ and failing LV membranes ( $n$ $=7$ ), shows absence of the superhigh affinity site and a decline in total muscarinic receptors in the failing LV. 
Table II. Agonist Binding

\begin{tabular}{|c|c|c|c|c|c|c|c|c|c|}
\hline & $\mathbf{K}_{11}$ & $\mathbf{K}_{\mathbf{1 2}}$ & $\mathbf{K}_{13}$ & $\mathbf{R}_{\mathbf{1}}$ & $\mathbf{R}_{\mathbf{2}}$ & $\mathbf{R}_{\mathbf{3}}$ & $\mathbf{R}_{\mathbf{1}}$ & $\mathbf{R}_{\mathbf{2}}$ & $\mathbf{R}_{\mathbf{3}}$ \\
\hline & & $\mu M$ & & & $\mathrm{fmol} / \mathrm{mg}$ & & & $\%$ & \\
\hline \multicolumn{10}{|l|}{ Carbachol } \\
\hline Normal LV $(n=7)$ & $0.01 \pm 0.01$ & $0.48 \pm 0.24$ & $4.68 \pm 1.01$ & $20 \pm 6$ & $55 \pm 10^{*}$ & $64 \pm 17$ & $14 \pm 5$ & $40 \pm 5$ & $46 \pm 5$ \\
\hline Failing LV $(n=7)$ & - & $1.11 \pm 0.96$ & $10.29 \pm 4.81$ & 0 & $29 \pm 6$ & $47 \pm 11$ & 0 & $38 \pm 6$ & $62 \pm 6$ \\
\hline \multicolumn{10}{|l|}{ Oxotremorine } \\
\hline Normal LV $(n=9)$ & - & $0.06 \pm 0.01$ & $3.53 \pm 0.90$ & 0 & $89 \pm 9^{*}$ & $68 \pm 12$ & 0 & $57 \pm 3$ & $43 \pm 3$ \\
\hline Failing LV $(n=9)$ & - & $0.08 \pm 0.05$ & $1.66 \pm 0.31$ & 0 & $56 \pm 9$ & $65 \pm 15$ & 0 & $46 \pm 5$ & $54 \pm 5$ \\
\hline
\end{tabular}

* High plus superhigh affinity sites greater in normal LV than failing LV, $P<0.05$.

cyclase activity produced by $0.1 \mathrm{mM}$ methacholine was no longer observed in normal LV (2,328 4432 pmol cyclic AMP/ mg per min) or in LV failure (786 $\pm 108 \mathrm{pmol}$ cyclic AMP/mg per min). This reversal by atropine of methacholine inhibition of isoproterenol stimulated adenylate cyclase activity results in adenylate cyclase activity similar to the maximal isoproterenol stimulated activity $(2,238 \pm 427 \mathrm{pmol}$ cyclic AMP/mg per min in normal hearts and $815 \pm 138 \mathrm{pmol}$ cyclic $\mathrm{AMP} / \mathrm{mg}$ per min in the failing LV). This demonstrates that the methacholine inhibition of adenylate cyclase activity is specific for the muscarinic cholinergic receptor.

Effects of methacholine on submaximal stimulation of adenylate cyclase activity by $0.3 \mu \mathrm{M}$ isoproterenol. Isoproterenol $(0.3 \mu \mathrm{M})$ plus GTP $(0.1 \mathrm{mM})$ were used to stimulate adenylate cyclase activity to examine the effects of a lower concentration of isoproterenol, which was near the $\mathrm{EC}_{50}$, and more sensitive to increasing concentrations of methacholine $(0.03-100 \mu \mathrm{M})$. Fig. 6 shows that in the LV sarcolemma from failing hearts, at any concentration of methacholine, adenylate cyclase was inhibited by only a minor fraction of that observed in the normal LV. Regression analysis was also conducted on these relationships. The slopes for normal and LV failure were tenfold different, $P<0.001$.

Quantitation of inhibitory GTP-binding proteins in LV failure (19). To use [ $\left.{ }^{32} \mathrm{P}\right] \mathrm{NAD} /$ pertussis toxin labeling as a method of quantitating the $\alpha$ subunits of $G_{i}$ and $G_{0}$, it was important to show that labeling of this protein was complete. This was

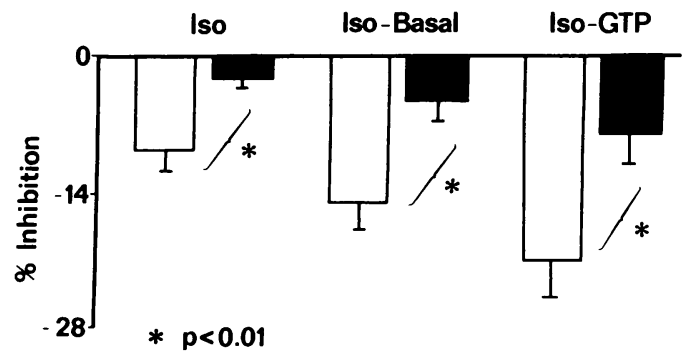

Figure 5. The percent inhibition by $1 \mu \mathrm{M}$ methacholine of isoproterenol $(0.1 \mathrm{mM})$ stimulated adenylate cyclase activity of cardiac sarcolemma from normal $(n=5)$ (open bars) and failing $(n=4) \mathrm{LV}$ (solid bars) is shown. On the left is the percent inhibition of isoproterenol $(0.1 \mathrm{mM})$ plus GTP $(0.1 \mathrm{mM})$-stimulated cyclase. The middle bars show the same data with basal activity subtracted, and on the right are the same data with the GTP $(0.1 \mathrm{mM})$-stimulated activity subtracted. demonstrated in two ways. First, saturation of labeling occurred at $60 \mathrm{~min}$ as shown in a typical experiment in Figs. 7 and 8 . During this time, $\left[{ }^{32} \mathrm{P}\right] \mathrm{NAD}$ concentrations were maintained as demonstrated by polyethyleneimine-cellulose thinlayer chromatography of reaction mixtures and subsequent autoradiography. Secondly, the amount of labeling was linear with respect to amount of sarcolemma protein added, and independent of the [ $\left.{ }^{32} \mathrm{P}\right] \mathrm{NAD}$ (range, 1 to $4.5 \mu \mathrm{M}$ ) and pertussis toxin (range, 3 to $12 \mu \mathrm{g} / \mathrm{ml}$ ) concentrations.

Using this technique, $G_{i}$ and $G_{0}$ were quantitated in sarcolemma from normal and failing LV. There is no significant difference in $G_{i}$ in normal $(23 \pm 2.5 \mathrm{pmol} / \mathrm{mg}$ protein, $n=5) \mathrm{vs}$. LV failure $(32 \pm 6.2 \mathrm{pmol} / \mathrm{mg}, n=4)$ or in $\mathrm{G}_{0}$ in normal $(10 \pm 2.1 \mathrm{pmol} / \mathrm{mg}) \mathrm{vs}$. $\mathrm{LV}$ failure $(12 \pm 2.1 \mathrm{pmol} / \mathrm{mg})$.

\section{Discussion}

Preliminary data from our laboratory using a crude membrane preparation suggested that a decrease in muscarinic receptors occurred in LV failure (5). Compared with the receptor density $(0.24 \mathrm{pmol} / \mathrm{mg}$ protein) detected in the crude membrane preparation employed in an initial study, a 23-fold enhancement in receptor content $(5.6 \mathrm{pmol} / \mathrm{mg}$ protein) was obtained in the highly enriched sarcolemma employed in the present investi-

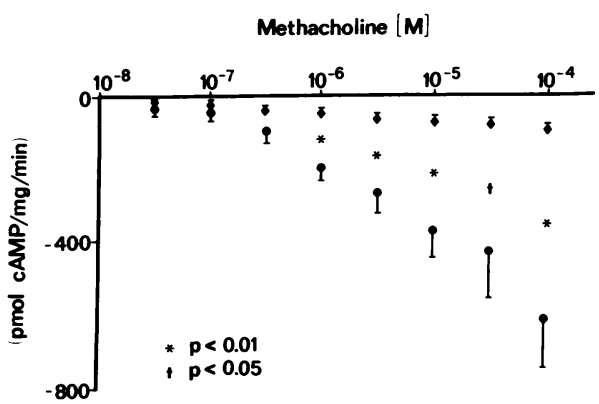

Figure 6. Adenylate cyclase was stimulated with isoproterenol $(0.3$ $\mu \mathrm{M})$ plus GTP $(0.1 \mathrm{mM})$ in sarcolemma from normal $\mathrm{LV}$ $(1,964 \pm 393 \mathrm{pmol} / \mathrm{mg}$ per $\mathrm{min})(n=6)$ and from failing $\mathrm{LV}(631 \pm 77$ $\mathrm{pmol} / \mathrm{mg}$ per $\min )(n=5)$, in the presence or absence of increasing concentrations of methacholine $(0.03-100 \mu \mathrm{M})$ to inhibit the production of cyclic AMP. In comparison to sarcolemma from normal LV (circles), there is a marked diminution of methacholine-mediated adenylate cyclase inhibition in sarcolemma from failing LV (diamonds). 


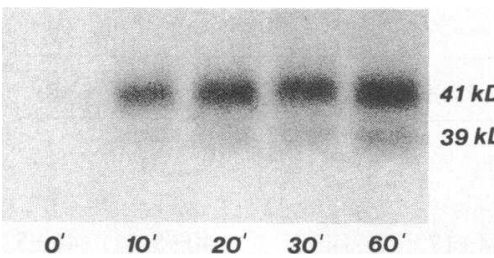

Figure 7. This figure demonstrates the ADP ribosylation of $\mathrm{G}_{\mathrm{i}}$ and $\mathrm{G}_{0}$ in solubilized canine sarcolemma membranes. Each lane contains $1.5 \mu \mathrm{g}$ protein incubated with $3 \mu \mathrm{g} / \mathrm{ml}$

pertussis toxin and $1.0 \mu \mathrm{M}\left[{ }^{32} \mathrm{P}\right] \mathrm{NAD}$ at $30^{\circ} \mathrm{C}$. The reaction was stopped at the following time points: $0,10,20,30$, and $60 \mathrm{~s}$. Note the ability to separate labeled $G_{i}$ and $G_{0}(\approx 41,000$ and $39,000 \mathrm{D}$, respectively) as two distinct bands.

gation. The current investigation, using this enriched sarcolemmal preparation (8), confirms the previous finding of decreased muscarinic receptor density in heart failure. While muscarinic receptor density in the sarcolemma of failing hearts is reduced, the absolute number of receptors per cell is not equivalently reduced, since myocyte hypertrophy occurs in this model of heart failure. The decreased density of muscarinic receptors could not be attributed to differences in the yield of membrane protein from each heart, since these values were similar in the normal and failing hearts. However, it is important to note that this reduction in density is not a generalized phenomenon. Firstly, as previously reported from our laboratory, $\beta$-adrenergic density is actually increased in the same sarcolemma prepared from the failing LV. Secondly, the sarcolemma marker $\mathrm{Na}^{+}, \mathrm{K}^{+}$-ATPase activity was similar in the two groups. Thirdly, the content of the inhibitory GTP protein, $G_{i}$, and another pertussis toxin substrate, $G_{0}$, were not decreased. The content of $G_{0}$ was quantitated, since reconstitution studies by Florio and Sternweis (20) suggest that $G_{0}$, as well as $G_{i}$, may couple to the muscarinic receptor.

Various mechanisms can be suggested that could lead to a reduction in muscarinic receptors as a secondary event. For example, a loss of sympathetic or parasympathetic innervation could be responsible since muscarinic receptors are associated with sympathetic as well as parasympathetic neurons $(21,22)$. In fact, heart failure is characterized by decreased myocardial



Figure 8. Time course of labeling of pertussis toxin substrate $\left(G_{i}\right.$ plus $\mathrm{G}_{0}$ ) of solubilized sarcolemma from two normal (open symbols) and one failure ( filled symbols) animal is shown. Note that saturation is nearly achieved by $30 \mathrm{~min}$. norepinephrine stores $(5,23)$. However, in a model of total cardiac denervation, where sympathetic denervation is more complete than in this heart failure model, we detected only a $20 \%$ decrease in muscarinic receptor density (24). Furthermore, in terms of the parasympathetic system, Roskoski et al. (25) have previously reported in an experimental model of heart failure in the guinea pig, that parasympathetic innervation as assessed by choline acetyl transferase levels, was reduced per unit weight, but not reduced in the entire ventricle. Their findings parallel our observations for muscarinic receptor density, which was reduced per milligram protein in the current investigation, but was not reduced in the entire ventricle, since hypertrophy had almost doubled the ventricular weight.

In the present investigation, agonist binding studies with carbachol and oxotremorine were also performed. Computer modeling of the binding data with carbachol indicated that there were three affinity states for the muscarinic receptor in the normal LV: superhigh, high, and low. In LV failure, agonist inhibition of $\left[{ }^{3} \mathrm{H}\right] \mathrm{QNB}$ binding confirmed the reduction in the total number of muscarinic receptors with specific reduction in high affinity sites and virtual absence of the superhigh affinity sites. With oxotremorine, only high and low affinity sites were observed in the normal LV, and there was a decrease in high affinity receptors in the failing LV. Similar modeling of agonist competition curves to three sites for carbachol and to two sites for oxotremorine has been reported previously (17). The mechanism underlying this difference has not been determined. As with the $\beta$-adrenergic receptor and other hormone receptors coupled to the stimulatory GTP protein, $G_{s}$, it has been postulated that the agonist high affinity state of the muscarinic receptor represents the "coupled" form of the receptor. Again, as with stimulatory hormone receptors, guanine nucleotides shift these receptors to a uniform low affinity state. Whether the ternary complex model of hormone, receptor and $G$ protein, which represents the high affinity $\beta$-receptor agonist binding state and which dissociates in the presence of guanine nucleotides, can also explain the shifts observed in muscarinic receptor binding, has yet to be determined.

We had expected, in fact, that a reduction in the levels of $G_{i}$ might be detected for two reasons. First, the specific loss of the high affinity form of the muscarinic receptor as discussed above suggested a potential deficiency in coupling to an inhibitory $\mathrm{G}$ protein. Secondly, our group has previously reported on a similar finding for the $\beta$-receptor, i.e., loss of high affinity $\beta$-agonist binding sites (despite an increase in $\beta$-adrenergic receptors as detected by antagonist binding) and loss of adenylate cyclase stimulation via both $\beta$-adrenergic receptors and sodium fluoride or $\mathrm{Gpp}(\mathrm{NH}) \mathrm{p}$ stimulation (5). Recently, we have confirmed that the level of the GTP stimulatory protein, $\mathrm{G}_{s}$, is reduced by $>50 \%$ in these membranes, whether quantitated by cholera toxin labeling or by reconstitution into $\$ 49$ cyc-membranes (26). However, in the case of the muscarinic receptor, a parallel decrease in its coupling protein, $G_{i}$, was not found. One possibility based on these observations is that some primary modification of the receptor itself, either pre- or posttranslational, has occurred in heart failure, which leads to the loss of that portion of the receptor pool able to bind agonists with high affinity. The mechanism of modification might involve a posttranslational event such as phosphorylation. A second possibility is that, although the density of the GTP- 
binding proteins $G_{i}$ and $G_{0}$, which have been shown to couple to the muscarinic receptor, is not reduced in heart failure, their functional activity in coupling the muscarinic receptor to adenylate cyclase may be abnormal. Recent evidence suggests that the population of the stimulatory $G$ protein, $G_{s}$, for example, is not homogeneous, but rather represents isoforms generated from alternative splicing of a single RNA transcript $(27,28)$. It is possible then that a reduction in the activity of the GTP inhibitory proteins might occur if different isoforms of $G_{i}$ are expressed in heart failure. Recently, highly homologous forms of $\mathrm{G}_{\mathrm{i}}$, likely encoded for by at at least three distinct genes, have been identified (29). Alternatively, posttranslational modification of these proteins could have occurred. For example, $G_{i}$ alpha can be phosphorylated by protein kinase $C$. Because this reaction has not been demonstrated to occur in the intact cell (30), its physiological significance, however, remains in question.

We also attempted to directly examine this inhibitory pathway by measuring the ability of $\mathrm{Gpp}(\mathrm{NH}) \mathrm{p}$ to inhibit forskolin-stimulated adenylate cyclase activity, thus bypassing the muscarinic receptor. However, unlike the inhibitory effect reported in other systems including liver and LLCPK $_{1}$ cells (31), no significant inhibition of forskolin-mediated adenylate cyclase stimulation in sarcolemma is observed over a wide range of $\mathrm{Gpp}(\mathrm{NH}) \mathrm{p}$ concentrations (unpublished data).

To determine if the alterations in muscarinic receptors in heart failure were of functional significance, we compared the extent of muscarinic inhibition of adenylate cyclase activity (9) in normal and failing LV. Depression of methacholine-mediated adenylate cyclase inhibition in the LV sarcolemma from failing hearts is readily apparent from Fig. 6, which shows that at any concentration of methacholine, adenylate cyclase was inhibited by only a fraction of that observed in the normal LV. Statistical evaluation of the rate of change in adenylate cyclase activity with increasing concentrations of methacholine was carried out by regression analysis. The slopes for normal and LV failure were tenfold different, $P<0.001$. Clearly the decrease in both basal and stimulated adenylate cyclase activity in heart failure makes such a comparison problematic. Nevertheless, even at a 100-fold greater concentration of methacholine, significantly less inhibition of adenylate cyclase activity was observed in LV failure as compared with normal LV. For example, if adenylate cyclase activity is stimulated with $0.3 \mu \mathrm{M}$ isoproterenol and then inhibited by $100 \mu \mathrm{M}$ methacholine, the inhibition was significantly less in the failing $\mathrm{LV}(58 \pm 17 \mathrm{pmol} / \mathrm{mg}$ per min) than that seen in the normal LV with $1 \mu \mathrm{M}$ methacholine $(210 \pm 40 \mathrm{pmol} / \mathrm{mg}$ per min). Under such conditions, the absolute number of muscarinic receptors occupied by agonists in the heart failure membranes would be comparable with that in the normal membranes.

In summary, this is the first study to demonstrate (i) a reduction in the density of cardiac muscarinic receptors, (ii) an alteration in agonist binding, as well as (iii) depression of muscarinic inhibition of adenylate cyclase activity, in a chronic animal model of LV failure. While a defect in the muscarinic receptor pathway distal to the receptor may also exist, the levels of $G_{i}$ were not reduced in failure. However, the decrease in muscarinic receptor density and, in particular, the high affinity agonist-binding component could explain previous observations that parasympathetic control of cardiac function is defective both in animals $(4)$ and in patients $(2,3)$ with heart failure.

\section{Acknowledgments}

We are grateful to John Newell, Director of the Cardiac Computer Center at the Massachusetts General Hospital, for his advice concerning the statistics and computer modeling of the agonist competition curves.

This work was supported in part by U. S. Public Health Service grants HL-38070, RR-00168, HL-19259, HL-37404, and HL-01909. D. L. Lee was supported by the Sarnoff Medical Foundation.

\section{References}

1. Abboud, F. M., H. A. Fozzard, J. P. Gilmore, and D. J. Reis, editors. 1981. Disturbances in Neurogenic Control of the Circulation. Williams \& Wilkins Co., Baltimore. 263 pp.

2. Jose, A. D., and R. R. Taylor. 1969. Autonomic blockade by propranolol and atropine to study intrinsic myocardial function in man. J. Clin. Invest. 48:2019-2031.

3. Eckberg, D. L., M. Drabinsky, and E. Braunwald. 1971. Defective cardiac parasympathetic control in patients with heart disease. $N$. Engl. J. Med. 285:877-883.

4. Higgins, C. B., S. F. Vatner, D. L. Eckberg, and E. Braunwald. 1972. Alterations in the baroreceptor reflex in conscious dogs with heart failure. J. Clin. Invest. 51:715-724.

5. Vatner, D. E., S. F. Vatner, A. M. Fujii, and C. J. Homcy. 1985. Loss of high affinity cardiac beta-adrenergic receptors in dogs with heart failure. J. Clin. Invest. 76:2259-2264.

6. Vatner, S. F., D. Franklin, R. L. Van Citters, and E. Braunwald. 1970. Effects of carotid sinus nerve stimulation on blood-flow distribution in conscious dogs at rest and during exercise. Circ. Res. 27:495-503.

7. Scher, A. M., and A. C. Young. 1970. Reflex control of heart rate in the unanesthetized dog. Am. J. Physiol. 218:780-789.

8. Jones, L. R., and H. R. Besch. 1984. Isolation of canine cardiac sarcolemmal vesicles. In Methods in Pharmacology. Vol. 5. A. Schwartz, editor. Plenum Publishing Corp., New York. 1-12.

9. Watanabe, A. M., M. M. McConnaughey, R. A. Strawbridge, J. W. Fleming, L. R. Jones, and H. R. Besch, Jr. 1978. Muscarinic cholinergic receptor modulation of $\beta$-adrenergic receptor affinity for catecholamines. J. Biol. Chem. 253:4833-4836.

10. Gilman, A. G. 1984. Guanine nucleotide-binding regulatory proteins and dual control of adenylate cyclase. J. Clin. Invest. 73:1-4.

11. Bokoch, G. M., T. Katada, J. K. Northup, M. Ui, and A. G. Gilman. 1984. Purification and properties of the inhibitory guanine nucleotide-binding regulatory component of adenylate cyclase. J. Biol. Chem. 259:3560-3567.

12. Longabaugh, J. P., D. E. Vatner, R. M. Graham, and C. J. Homcy. 1986. NADP improves the efficiency of cholera toxin catalyzed ADP-ribosylation in liver and heart membranes. Biochem. Biophys. Res. Commun. 137:328-333.

13. Munson, P. J., and D. Rodbard. 1980. Ligand: a versatile computerized approach for characterization of ligand-binding systems. Anal. Biochem. 107:220-239.

14. Salomon, Y., C. Londos, and M. Rodbell. 1974. A highly sensitive adenylate cyclase assay. Anal. Biochem. 58:541-548.

15. Lowry, O. H., N. J. Rosebrough, A. L. Farr, and R. J. Randall. 1951. Protein measurement with folin phenol reagent. J. Biol. Chem. 193:265-275.

16. Armitage, P. 1975. Statistical inference. In Statistical Methods in Medical Research. Blackwell Scientific Publications, London. 99-146.

17. Birdsall, N. J. M., E. C. Hulme, and A. Burgen. 1980. The character of the muscarinic receptors in different regions of the rat brain. Proc. R. Soc. Lond. B Biol. Sci. 207:1-12. 
18. Burgisser, E., A. DeLean, and R. J. Lefkowitz. 1982. Reciprocal modulation of agonist and antagonist binding to muscarinic cholinergic receptor by guanine nucleotide. Proc. Natl. Acad. Sci. USA. 79:1732-1736.

19. Cerione, R. A., C. Staniszewski, M. G. Caron, R. J. Lefkowtiz, J. Codina, and L. Birnbaumer. 1985. A role for $N_{i}$ in the hormonal stimulation of adenylate cyclase. Nature (Lond.). 318:293-295.

20. Florio, V. A., and P. C. Sternweis. 1985. Reconstitution of resolved muscarinic cholinergic receptors with purified GTP-binding proteins. J. Biol. Chem. 260:3477-3483.

21. Sharma, V. K., and S. P. Banerjee. 1978. Presynaptic muscarinic cholinergic receptors. Nature (Lond.). 272:276-278.

22. Story, D. D., M. S. Briley, and S. Z. Langer. 1979. The effects of chemical sympathectomy with 6-hydroxydopamine on $\alpha$-adrenoceptor and muscarinic cholinoceptor binding in rat heart ventricle. Eur. $J$. Pharmacol. 57:423-426.

23. Chidsey, C. A., E. Braunwald, and A. G. Morrow. 1965. Catecholamine excretion and cardiac stores of norepinephrine in congestive heart failure. Am. J. Med. 39:442-451.

24. Vatner, D. E., M. Lavallee, J. Amano, A. Finizola, C. J. Homcy, and S. F. Vatner. 1985. Mechanisms of supersensitivity to sympathomimetic amines in the chronically denervated heart of the conscious dog. Circ. Res. 57:55-64.

25. Roskoski, R., Jr, P. G. Schmid, H. E. Mayer, and F. M. Ab- boud. 1975. In vitro acetylcholine biosynthesis in normal and failing guinea pig hearts. Circ. Res. 36:547-552.

26. Longabaugh, J. P., D. E. Vatner, S. F. Vatner, and C. J. Homcy. 1988. Decreased stimulatory guanosine triphosphate-binding protein in dogs with pressure-overload left ventricular failure. J. Clin. Invest. 81:420-424.

27. Robishaw, J. D., M. D. Smigel, and A. G. Gilman. 1986. Molecular basis for two forms of the G-protein that stimulates adenylate cyclase. J. Biol. Chem. 261:9587-9590.

28. Bray, P., A. Carter, C. Simons, V. Guo, C. Puckett, J. Kamholz, and A. Spiegel. 1986. Human cDNA clones for four species of $G_{\infty}$ signal transduction protein. Proc. Natl. Acad. Sci. USA. 83:8893-8897.

29. Jones, D. T., and R. R. Reed. 1987. Molecular cloning of 5 GTP-binding protein cDNA species from rat olfactory neural epithelium. J. Biol. Chem. 262:14241-14249.

30. Katada, T., A. G. Gilman, Y. Watanabe, S. Bauer, and K. H. Jacobs. 1985. Protein kinase $C$ phosphorylates the inhibitory guaninenucleotide-binding regulatory component and apparently suppresses its function in hormonal inhibition of adenylate cyclase. Eur. J. Biochem. 151:431-437.

31. Skorecki, K. L., A. S. Verkman, and D. A. Ausiello. 1987. Cross talk between stimulatory and inhibitory guanosine 5'-triphosphate binding proteins: role in activation and desensitization of the adenylate cyclase response to vasopressin. Biochemistry. 26:639-645. 